\title{
GENDER IM MUSIKVIDEO. EINE BIBLIOGRAPHIE DER FORSCHUNGSLITERATUR
}

\author{
Carsten Heinke
}

Die Bibliographie verzeichnet Titel, die sich auf die Themenbereiche »Gender« und »Musikvideoclips« beziehen. Arbeiten zu Videoclips, in denen Gender-Fragen keine oder eine bloß untergeordnete Rolle spielen, fehlen daher ebenso wie Publikationen der Gender Studies ohne expliziten Bezug auf das Musikfernsehen - selbst wenn es darin um andere, evtl. übertragbare Medienformate geht. In die Bibliographie aufgenommen wurden hingegen Arbeiten zu Frauen- und Männerbildern in Musikvideoclips, zu geschlechtsspezifischen Rezeptionsweisen sowie zum Status von Frauen bei Sendern des Musikfernsehens.

Ansager, Julie L. / Roe, Kimberly (1999). »Country Music Video in Country's Year of the Woman. «In: Journal of Communication 49, Nr. 1, S. 69-87.

Bechdolf, Ute (1994). »Musikvideos im Alltag. Geschlechtsspezifische Rezeptionsweisen.« In: Gender und Medien. Ein Textbuch zur Einführung. Hg. v. MarieLuise Angerer und Johanna Dorer. Wien: Braumüller, S. 186-193.

Bechdolf, Ute (1995). »Musikvideos im Alltag. Geschlechtspezifische Rezeptionsweisen.« In: Popmusic - Yesterday - Today - Tomorrow. 9 Beiträge vom 8. Internationalen Studentischen Symposium für Musikwissenschaft Köln 1993. Hg. v. Markus Heuger und Matthias Prell. Regensburg: ConBrio, S. 123-132.

Bechdolf, Ute (1996). "Watching Madonna. Anmerkungen zu einer feministischen Medien-/Geschlechterforschung. "In: Geschlechtsspezifische Aspekte des Musiklernens. Hg. v. Hermann J. Kaiser. Essen: Blaue Eule, S. 23-44.

Bechdolf, Ute (1996). »Musik Video HIStories. Geschichte - Diskurs - Geschlecht. « In: Models oder Machos? Frauen- und Männerbilder in den Medien. Hg v. Christiane Hackl, Elizabeth Prommer und Brigitte Scherer. Konstanz: UVK Medien, S. 277-299.

Bechdolf, Ute (1997). „Verhandlungssache >Geschlecht<. Eine Fallstudie zur kulturellen Herstellung von Differenz bei der Rezeption von Musikvideos.« In: Kultur, Medien, Macht. Cultural Studies und Medienwissenschaft. Hg. v. Andreas Hepp und Rainer Winter. Opladen: Westdeutscher Verlag, S. 201-214.

Bechdolf, Ute (1997). »De- und Rekonstruktion von Geschlecht beim Musikfernsehen. Eine Fallstudie. «In: Step Across the Border. Neue musikalische Trends neue massenmediale Kontexte. Hg. v. Helmut Rösing (= Beiträge zur Popularmusikforschung 19/20). Karben: CODA, S. 184-199. 
Bechdolf, Ute (1997). »Vom Ultra-Sexismus zum emanzipatorischen Innovationsraum? Geschlecht in Musikvideos. "In: Das Argument 39, Nr. 6, S. 787-798.

Bechdolf, Ute (1998). »Männlich versus weiblich? De- und Rekonstruktionen der Geschlechterdifferenz in Musikvideos. «In: Im Wyberspace. Mädchen und Frauen in der Medienlandschaft. Dokumentation, Wissenschaft, Essay, Praxismodelle. Hg. v. Dagmar Beinzger u.a. (= Schriften zur Medienpädagogik 26). Bielefeld: Vorstand der GMK, S. 124-136.

Bechdolf, Ute (1999). Puzzling Gender. Re- und Dekonstruktionen von Geschlechterverhältnissen im und beim Musikfernsehen. Weinheim: Deutscher Studien Verlag.

Bechdolf, Ute (2000). »Nur scharfe Girlies und knackige Boys? Traditionelle und innovative Geschlechterbilder in Musikvideos. «In: Gender - Geschlechterverhältnisse im Pop (= Testcard. Beiträge zur Popgeschichte 8). Mainz: Ventil, S. 30-37.

Bechdolf, Ute (2002). »Puzzling Gender. Jugendliche verhandeln Geschlecht in und beim Musikfernsehen.« In: Wozu Jugendliche Musik und Medien gebrauchen. Jugendliche Identität und musikalische und mediale Geschmacksbildung. Hg. v. Renate Müller u.a. Weinheim: Juventa, S. 222-230.

Bernold, Monika (1992). »)Let's talk about clips<. Feministische Analysen von MTV. Ein Blick auf die anglo-amerikanische Diskussion.« In: Medien Journal 16, Nr. 3, S. 133-139.

Bloss, Monika (1998). "Geschlecht als musikkulturelle Performance. Androgyne Images von PopmusikerInnen und das Spiel mit der ssexuellen Differenz‘."In: Gender Studies \& Musik. Geschlechterrollen und ihre Bedeutung für die Musikwissenschaft. Hg. v. Stefan Fragner, Jan Hemming und Beate Kutschke (= Forum Musikwissenschaft 5). Regensburg: ConBrio, S. 189-203.

Bloss, Monika (2001). »Musik(fern)sehen und Geschlecht hören? Zu möglichen (und unmöglichen) Verhältnissen von Musik und Geschlecht. Oder: Geschlechterkonstruktionen im Videoclip. «In: Rock- und Popmusik. Hg. v. Peter Wicke (= Handbuch der Musik im 20. Jahrhundert 8). Laaber: Laaber, S. 187-225.

Blume, Jutta (1993). »Neue Ästhetik - Alter Sexismus? Frauenbilder in populären Musikvideoclips. Popularität vs. Eigensinn.«In: Feministische Streifzüge durchs Punkte-Universum. Medienkunst von Frauen. Hg. v. Heidi Hutschenreuter und Claudia Schurian. Essen: Edition Filmwerkstatt, S. 93-109.

Blume, Jutta (1996). »Rock-Ladies und Pop-Divas. Frauenbilder und Weiblichkeitsvorstellungen im Videoclip. «In: Musik und Bildung 28, Nr. 1, S. 30-34.

Blume, Jutta (1998). »Tic, Tac, Toe - Spice Girls \& Co. Starimages und Geschlechterrollen in Musikvideoclips des Pop-Mainstreams. « In: Musik und Unterricht 9, H. 51, S. 26-35.

Brown, Jane D. / Campbell, Kenneth (1986). »Race and Gender in Music Videos: The Same Beat But a Different Drummer.«In: Journal of Communication 36, Nr. 1, S. 94-106.

Brown, Jane D. / Schulze, Laurie (1990). "The Effects of Race, Gender, and Fandom on Audience Interpretations of Madonna's Music Videos. «In: Journal of Communication 40, Nr. 2, S. 88-102.

Bullerjahn, Claudia (2000). »Do Music Videos Stir up Sex and Violence in Our Teenagers? In: Music Forum. Journal of the Music Council of Australia 6, Nr. 4, S. 2629.

Bullerjahn, Claudia (2001). „Populäres und Artifizielles in den Musikvideos von Madonna. "In: Das Populäre in der Musik des 20. Jahrhunderts - Wesenszüge und Erscheinungsformen. Hg. v. Claudia Bullerjahn und Hans-Joachim Erwe. Hildesheim: Olms. 
Curry, Ramona (1990). »Madonna from Marilyn to Marlene - Pastiche and/or Parody?«In: Journal of Film and Video 42, Nr. 2, S. 15-30.

Denski, Stan / Sholle, David (1992). »Metal Men and Glamour Boys. Gender Performance in Heavy Metal.«In: Men, Masculinity and the Media. Hg. v. Steve Craig. London: Sage, S. 41-60.

Fiske, John (2000). Lesarten des Populären. Wien: Turia und Kant, S. 96-150.

Frank, Lisa / Smith, Paul (Hg.) (1993). Madonnarama. Essays on Sex and Popular Culture. Pittsburgh: Cleis Press.

Freccero, Carla (1992). »Our Lady of MTV: Madonna's >Like a Prayer<.«In: Feminism and Postmodernism. A Special Issue of Boundary 2. An International Journal of Literature and Culture 19, Nr. 2, S. 163-183.

Glogauer, Werner (1988): "Sex und Gewalt als auffälligste Inhalte von Videoclips.« In: Musik und Bildung 11, S. 835-840.

Goldstein, Lynda (1996). "Revamping MTV: Passing for Queer Culture in the Video Closet.« In: Queer Studies: A Lesbian, Gay, Bisexual, and Transgender Anthology. Hg. v. Brett Beemyn und Mickey Eliason. New York: New York University Press, S. 262-279.

Grigat, Nicoläa (1995). Madonnenbilder. Dekonstruktive Ästhetik in den Videobildern Madonnas. (= Studien zum Theater, Film und Fernsehen 21). Frankfurt/M. u.a.: Lang.

Hansen, Christine H. (1989). »Priming Sex-Role Stereotypic Event Schemas with Rock Music Videos. Effects on Impression Favorability, Trait Inferences, and Recall of a Subsequent Male-Female Interaction. "In: Basic and Applied Social Psychology 10, Nr. 4, S. 371-391.

Hansen, Christine H. / Hansen, Ronald D (1988). »How Rock Music Videos Change What's Seen When Boy Meets Girl: Priming Stereotypic Appraisal of Social Interactions. «In: Sex Roles 19, S. 287-316.

Hansen, Christine H. / Hansen, Ronald D. (1990). "The Influence of Sex and Violence on the Appeal of Rock Music Videos.« In: Communication Research 17, S. 212-234.

Hurley, Jennifer M. (1994). »Music Video and the Construction of Gendered Subjectivity (or How Being a Music Video Junkie Turned me Into a Feminist. « In: Popular Music 13, Nr. 3, S. 327-338.

Kalis, Pamela / Neuendorf, Kimberly (1989). »Aggressive Cue Prominence and Gender Participation in MTV. «In: Journalism Quarterly 66, Nr. 1, S. 148-154.

Kaplan, E. Ann (1986). »History, the Historical Spectator and Gender Address in Music Television. «In: Journal of Communication Inquiry 10, Nr. 1, S. 3-14.

Kaplan, E. Ann (1987). Rocking Around the Clock: Music Television, Postmodernism and Consumer Culture. New York: Methuen.

Kaplan, E. Ann (1987). »Feminist Criticism and Television.«In: Channels of Discourse: Television and Contemporary Criticism. Hg. v. Robert C. Allen. Chapel Hill, NC: University of North Carolina Press, S. 211-253.

Kaplan, E. Ann (1988). »Feminism / Oedipus / Postmodernism: The Case of MTV.« In: Postmodernism and Its Discontents: Theories - Practices. Hg. v. E. Ann Kaplan. New York: Verso, S. 30-44.

Kaplan, E. Ann (1990). »Whose Imaginary? The Television Apparatus, the Female Body und Textual Strategies in Select Rock Videos on MTV.«In: Female Spectators. Looking at Film and Television. Hg. v. E. Deidre Pribam. London, New York: Verso, S. 132-156.

Kaplan, E. Ann (1994). »Feminismus in der Postmoderne. MTV und alternative Videokunst von Frauen.«In: Visueller Sound. Musikvideos zwischen Avantgarde 
und Populärkultur. Hg. v. Cecilia Hausheer und Annette Schönholzer. Luzern: Zyklop, S. 118-133.

Kinder, Marsha (1987). »Phallic Film and the Boob Tube: The Power of Gender Identification in Cinema, Television, and Music Video.« In: OneTwoThreeFour 5, S. 33-49.

Kinder, Marsha (1991). "The Battle of the Sexes on MTV. «In: Media USA: Process and Effect. Hg. v. Arthur Asa Berger. New York: Longman, S. 224-232.

Knolle, Niels (1996). »>Weil ich ein Mädchen bin ...<. Symbolverständnis, Gebrauch und Funktionalisierung von Rockmusikinstrumenten im Kontext der Darstellung von Musikerinnen und Musikern in aktuellen Videoclips. "In: Geschlechtsspezifische Aspekte des Musiklernens. Hg. v. Hermann J. Kaiser. Essen: Blaue Eule, S. 45-72.

Lauretis, Teresa de (1987). Technologies of Gender. Essays on Theory, Film and Fiction. Bloomington: Indiana University Press.

Lewis, Lisa A. (1987). "Consumer Girl Culture. How Music Video Appeals to Women.« In: OneTwoThreeFour 5, S. 5-15.

Lewis, Lisa A. (1987). »Female Address in Music Video. «In: Journal of Communication Inquiry 11, Nr. 1, S. 73-84.

Lewis, Lisa A. (1987). »Form and Female Authorship in Music Video.«In: Communication 9, S. 355-377.

Lewis, Lisa A. (1990). Gender, Politics and MTV. Voicing the Difference. Philadelphia: Temple University Press.

Lewis, Lisa A. (1990). »Being Discovered. Female Address on Music Television.« In: Jump Cut 35, S. 2-15.

Lewis, Lisa A. (1993). »Being Discovered. The Emergence of Female Address on MTV. «In: Sound and Vision. The Music Video Reader. Hg. v. Simon Frith, Andrew Goodwin und Lawrence Grossberg. London: Routledge, S. 129-152.

Martin, Linda / Segrave, Kerry (1988). »Visual Violations. «In: Antirock. The Opposition to Rock 'n' Roll. Hg. v. dens. Hamden, CT: Archon Books, S. 273-279.

McClary, Susan (1990). »Living to Tell. Madonna's Resurrection of the Fleshly.«In: Genders 7, S. 1-21.

McDonald, Paul (1997). »Feeling and Fun. Romance, Dance and the Performing Male Body in the Take That Videos. «In: Sexing the Groove. Popular Music and Gender. Hg. v. Sheila Whiteley. London: Routledge, S. 277-294.

McRobbie, Angela (1994). Postmodernism and Popular Culture. London: Routledge.

Müller, Renate (1996). "Geschlechtsspezifisches Umgehen mit Videoclips. Erleben Mädchen Videoclips anders?« In: Geschlechtsspezifische Aspekte des Musiklernens. Hg. v. Hermann J. Kaiser. Essen: Blaue Eule, S. 73-93.

Oglesbee, Frank W. (1987). "Eurythmics. An Alternative to Sexism in Music Videos.« In: Popular Music and Society 11, Nr. 2, S. 53-64.

Paglia, Camille (1992). »Madonna I. Animality and Artificiality. Madonna II. Venus of the Radiowaves. «In: Dies., Sex. Art and American Culture. Essays. New York: Vintage, S. 3-13.

Paglia, Camille (1992). Die Masken der Sexualität. Berlin: Byblos.

Paglia, Camille (1993). Der Krieg der Geschlechter. Sex, Kunst und Medienkultur. Berlin: Byblos.

Pegley, Karen (2000). " simple economics? Images of gender and nationality on MuchMusic (Canada) and MTV (United States). « In: Women and Music 4, S. 1-17.

Rich, Michael u.a. (1998). »Agressors or Victims. Gender and Race in Music Video Violence. «In: Pediatrics 101, Nr. 4, S. 669-674. URL: http://www.lionlamb.org/ research_articles/Aggressors\%20or\%20Victims.pdf [Stand: 20.05.03]. 
Roberts, Robin (1991). »Music Videos, Performance and Resistance. Feminist Rappers. «In: Journal of Popular Culture 25, Nr. 2, S. 141-152.

Roberts, Robin (1994). »>Ladies First<. Queen Latifah's Afrocentric Feminist Music Video. «In: African American Review 28, S. 245-257.

Roberts, Robin (1996). »Independence Day. Feminist Country Music Videos.« In: Popular Music and Society 20, Nr. 1, S. 135-154.

Roberts, Robin (1996). Ladies First. Women in Music Videos. Jackson: University Press of Mississippi.

Rose, Tricia (1994). Black Noise. Rap Music and Black Culture in Contemporary America. Hanover, NH: Wesleyan University Press.

Savage, Jon (1990). »Tainted Love. The Influence of Male Homosexuality and Sexual Divergence on Pop Music and Culture since the War. «In: Consumption, Identity, and Style. Marketing, Meanings, and the Packaging of Pleasure. Hg. v. Alan Tomlinson. New York: Comedia, S. 153-171.

Savage, Jon (1996). Time Travel. Pop, Media and Sexuality 1976-96. London: Chatto \& Windus.

Schmidt, Eva (1999). »Eine Jagd durch die Nacht. The Prodigy und ihr ausgezeichneter/zensierter Clip >Smack my bitch up «. In: Viva MTV! Popmusik im Fernsehen. Hg. v. Klaus Neumann-Braun. Frankfurt/M.: Suhrkamp, S. 307-322.

Schmitting, Inge (1998). "Girls, Videos und bunte, fließende Bilder. Geschlechtsbewußte Medienaneignung von Mädchen.« In: Im Wyberspace. Mädchen und Frauen in der Medienlandschaft. Dokumentation, Wissenschaft, Essay, Praxismodelle. Hg. v. Dagmar Beinzger u.a. (= Schriften zur Medienpädagogik 26). Bielefeld: Vorstand der GMK, S. 214-221.

Schwichtenberg, Cathy (Hg.) (1993). The Madonna Connection. Representational Politics, Subcultural Identities, and Cultural Theory. Boulder, CO: Westview Press.

Seibel, Alexandra / Williams, Karen (2001). »Das Unbehagen an der Girl-Kultur. Wonder Woman, Delinquent Dykes und Gothic Girls als Paradigmen feministischer Filmpraxis. «In: Pop Unlimited? Imagetransfers in der aktuellen Popkultur. Hg. v. Christian Höller. Wien: Turia und Kant, S. 43-54.

Seibel, Alexandra / Williams, Karen (2001). »Image-making, Post-Riot-Grrrl: Interview mit der Videoregisseurin Jennifer Reeder.«In: Pop Unlimited? Imagetransfers in der aktuellen Popkultur. Hg. v. Christian Höller. Wien: Turia und Kant, S. 55-60.

Seidman, Steven A. (1992). »An Investigation of Sex-Role Stereotyping in Music Videos. "In: Journal of Broadcasting and Electronic Media 36, Nr. 2, S. 209-216.

Sherman, Barry L. / Dominick, Joseph R. (1986). »Violence and Sex in Music Videos. TV and Rock'n'Roll. «In: Journal of Communication 36, Nr.1, S. 79-93.

Signorielli, Nancy / McLeod, Douglas / Healy, Elaine (1994). "Gender Stereotypes in MTV Commercials. The Beat Goes On. «In: Journal of Broadcasting and Electronic Media 38, Nr.1, S. 91-102.

Slane, Andrea (2001). A Not So Foreign Affair. Fascism, Sexuality, and the Cultural Rhetoric of American Democracy [u.a. zum Video »Justify My Love« von Madonna]. Durham: Duke UP.

Sommers-Flanagen, Rita / Sommers-Flanagen, John / Davis, Britta (1993). "What's Happening on Music Television? A Gender Role Content Analysis. «In: Sex Roles 28, Nr. 11/12, S. 745-753.

Stockbridge, Sally (1987). »Music Video. Questions of Performance, Pleasure and Address." In: The Australian Journal of Media \& Culture 1, Nr. 2. URL: 
http://wwwmcc.murdoch.edu.au/ReadingRoom/1.2/Stockbridge.html [Zugriff: 12.05.03].

Stockbridge, Sally (1990). »Rock Video. Pleasure and Resistance.«In: Television and Women's Culture: The Politics of the Popular. Hg. v. Mary Ellen Brown. Newbury Park, CA: Sage, S. 102-113.

Treagus, Mandy (1999). »Gazing at the Spice Girls. Audience, Power and Visual Representation. "In: Musical Visions: selected conference proceedings from the 6th National Australia/New Zealand IASPM and the Inaugural Arnhem Land Performance Conference. Hg. v. Gerry Bloustien. Adelaide: Wakefield Press, S. 135141. URL: http://www.chloe.uwa.edu.au/outskirts/archive/VOL3/article2.html [Zugriff: 1.06.03].

Turim, Maureen (1996). »Gesang der Frauen, Gesten der Frauen. Musikvideos. « In: Frauen und Film 58/59, S. 25-44.

Vincent, Richard C. (1989). „Clio's Consciousness Raised? Portrayal of Women in Rock Videos Reexamined.«In: Journalism Quarterly 66, S. 155-160.

Vincent, Richard C. / Davis, Dennis K. / Boruszkowski, Lilly Ann (1987). "Sexism on MTV. The Portrayal of Women in Rock Videos. «In: Journalism Quarterly 64, Nr. 4, S. 750-755.

Waite, Bradley M. (1987). Popular Music Videos. A Content Analysis and SocialDevelopmental Investigation of Their Effects on Gender Orientation and Attitudes. Ann Arbor, MI: Universal Microfilms International, NEX 86-21641.

Wallbott, Harald G. (1992). "Sex, Violence, and Rock'n'Roll. Zur Rezeption von Musikvideos unterschiedlichen Inhalts. «In: Medienpsychologie 4, Nr. 1, S. 3-14.

Walser, Robert (1993). Running With the Devil. Power, Gender and Madness in Heavy Metal Music. Hanover, NJ: University of New England Press.

Walser, Robert (1993). „Forging Masculinity. Heavy-Metal Sounds and Images of Gender.« In: Sound and Vision. The Music Video Reader. Hg. v. Simon Frith, Andrew Goodwin und Lawrence Grossberg. London, New York: Routledge, S. $153-184$.

Whiteley, Sheila. (1997). "Seduced by the Sign. An Analyses of the Textual Links Between Sound and Image in Pop Videos."In: Sexing the Groove. Popular Music and Gender. Hg. v. Sheila Whiteley. London: Routledge, S. 259-275.

Whiteley, Sheila. (2000). „Challenging the Feminine. Annie Lennox, Androgyneity and Illusions of Identity. «In: Dies., Women and Popular Music. Sexuality, Identity and Subjectivity. London, New York: Routledge, S. 119-135.

Whiteley, Sheila. (2000). »Madonna, Eroticism, Autoeroticism and Desire.« In: Dies., Women and Popular Music. Sexuality, Identity and Subjectivity. London, New York: Routledge, S. 136-151.

Willis, Holly (1994). »Bait and Switch - Ködern und Verdrehen. Musikvideos von (Schwindel-)Künstlerinnen. «In: Visueller Sound. Musikvideos zwischen Avantgarde und Populärkultur. Hg. v. Cecilia Hausheer und Annette Schönholzer. Luzern: Zyklop, S. 134-149.

Young, Stephen E. (1991). »Like a Critique. A Postmodern Essay on Madonna's Postmodern Video >Like a Prayer<.« In: Popular Music and Society 15, Nr. 1, S. 59-68.

Zellers, Marcia (1998). „Die Verwegenen und die Schönen. MTV läßt Frauen alles zeigen.« In: Lips, Tits, Hits, Power? Popkultur und Feminismus. Hg. v. Anette Baldauf und Katharina Weingartner. Wien, Bozen: Folio, S. 126-135.

Zillmann, Dolf / Mundorf, Norbert (1987). »Image Effects in the Appreciation of Video Rock.«In: Communication Research 14, Nr. 3, S. 316-334. 